\title{
THE STRUCTURAL ANALYSIS OF SOCKET INLAYS OF THE HIP ENDOPROSTHESIS
}

\author{
Robert Karpiński ${ }^{1}$, Łukasz Jaworski \\ ${ }^{1}$ Lublin University of Technology, Faculty of Electrical Engineering and Computer Science, \\ email: robert.karpinski@pollub.edu.pl \\ ${ }^{2}$ Poznan University of Technology, Faculty of Mechanical Engineering and Management, \\ email: lukasz.m.jaworski@student.put.poznan.pl
}

\section{ABSTRACT}

The paper presents results of the preliminary structural analysis of socket inlays model of the endoprosthesis of the hip joint. Basics of anatomy and biomechanical analysis of the hip joint were introduced. The prototype of socket inlay of the hip endoprosthesis was modeled using Solid Edge ST8 software. After determining physical properties of structural materials for socket inlays, the Finite Elements Analysis of the model was conducted using SolidWorks software under various load conditions. Finally the results of analysis were presented.

KEYWORDS: endoprosthesis, finite element method, hip joint, socket inlay

\section{ANALIZA STRUKTURALNA WKŁADKI ENDOPROTEZY STAWU BIODROWEGO STRESZCZENIE}

W pracy przedstawiono wyniki wstępnej analizy strukturalnej wkładki endoprotezy stawu biodrowego. Zaprezentowano podstawowe informacje $z$ anatomii oraz biomechaniki stawu biodrowego. Model wkładki endoprotezy wykonano z wykorzystaniem oprogramowania Solid Edge ST8. Po określeniu właściwości fizycznych materiałów stosowanych na wkładki endoprotezy przeprowadzono analizę Metodą Elementów Skończonych w programie SolidWorks dla różnych warunków obciążenia. Zaprezentowano uzyskane wyniki.

SŁOWA KLUCZOWE: Endoproteza, wkładka endoprotezy, Metoda Elementów Skończonych, staw biodrowy

\section{Introduction}

Today's attention in medicine, given to increasingly aged population, is firmly focused on attending elderly people with their medical conditions with a great contribution of orthopedic injuries. Hence there is the high level of technology affiliated with manufacturing prosthetic implants, such as endoprosthesis of a hip joint.

Progressing advancement in materials science presents an opportunity to modify existing designs with a use of better materials. Due to improved mechanical and tribological properties of given new materials, it is significantly easier to prevent prosthetic elements from wear-related damages, which translates both into longer lifetime of the endoprosthesis and greater comfort for a treated patient.

The study focuses on changes in a stress distribution and deformations in the socket inlay of the hip endoprosthesis resulting from the use of different materials.

\section{Anatomical background}

Human hip joint is one of the most exploited synovial joints, hence it is at greater risk of degenerative changes. It consists of a pelvic bone, connected to the spine, with an acetabulum acting 
as an articular surface, the femur with the head located on the articular surface and the joint capsule surrounding these structures, filled with synovial fluid to reduce friction. Additional elements are strong ligaments, which suppress excessive movement around the joint. Hip joint's main role is to transfer body weight onto legs and enable rotational moves in horizontal, sagittal and vertical axis.

The implications of damages affecting the structures of the hip joint along with more detailed anatomy and biomechanics are described by Karpiński et al. [1, 2, 5].

\section{The methodology of the study}

\subsection{The model of the endoprosthesis of the hip joint}

For the purposes of studies the design and virtual prototype of the bipolar endoprosthesis of the hip joint was made, with such parts as prosthetic shaft inserted into properly prepared thigh bone of a patient, removable head, prosthetic socket and socket inlay, both spherically-shaped. Further information about the model can be found in Karpiński et al. [2]

\subsection{The structural analysis of the socket inlay}

The preliminary structural analysis of the socket inlay is performed using Finite Elements Method in Solidworks Simulation software. The model was fixed on the surface of the socket and the force was applied to the shaft of the endoprosthesis with value matching the value of the body weight (Fig. 1.). In performed studies the human body weight was set on $784,8 \mathrm{~N}$ (an equivalent of $80 \mathrm{~kg}$ ), which was then assumed as $100 \%$ of body weight (\%BW). Examination was conducted for 100 and $200 \%$ BW.

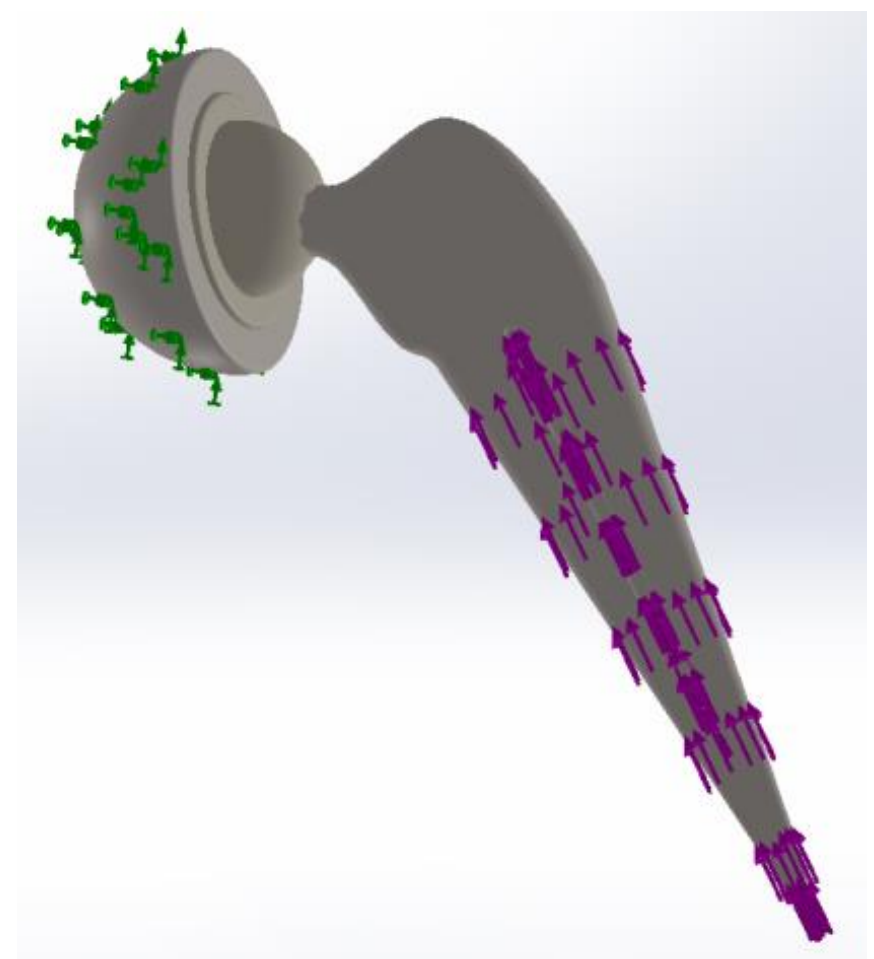

Fig. 1. Places of fixing the model and application of the force

Two materials were chosen to be studied: ultra-high-molecular-weight polyethylene (UHMWPE) and BIOLOX ${ }^{\circledR}$ delta ceramic from CeramTech. Polyethylene socket inlay was intended to be paired with titanium head, while ceramic was used in both socket inlay and head, as suggested by Dickinson et al. [3]. Then, materials were assigned to each element in the simulation. Properties of materials are presented in Table 1. Results of the analysis are shown in Figs. $2-5$ and in Table 2. 
Table 1. Table of materials $[3,4]$

\begin{tabular}{|c|r|r|r|r|}
\hline Material & Element & $\begin{array}{c}\text { Young's } \\
\text { modulus [MPa] }\end{array}$ & Poisson's ratio [-] & $\begin{array}{c}\text { Density } \\
{\left[\mathbf{g} / \mathbf{c m}^{3}\right]}\end{array}$ \\
\hline $\begin{array}{c}\text { Titanium alloy } \\
\text { Ti-6Al-4V }\end{array}$ & $\begin{array}{c}\text { Socket, shaft, } \\
\text { head }\end{array}$ & $1.048^{*} 10^{5}$ & 0.31 & 4.43 \\
\hline $\begin{array}{c}\text { Ultra-high- } \\
\text { molecular-weight } \\
\text { polyethylene }\end{array}$ & Socket inlay & 800 & 0.46 & 0.96 \\
\hline $\begin{array}{c}\text { BIOLOX }{ }^{\circledR} \text { delta } \\
\text { ceramic }\end{array}$ & $\begin{array}{c}\text { Socket inlay, } \\
\text { head }\end{array}$ & $3.5^{*} 10^{5}$ & 0.22 & 3.69 \\
\hline
\end{tabular}
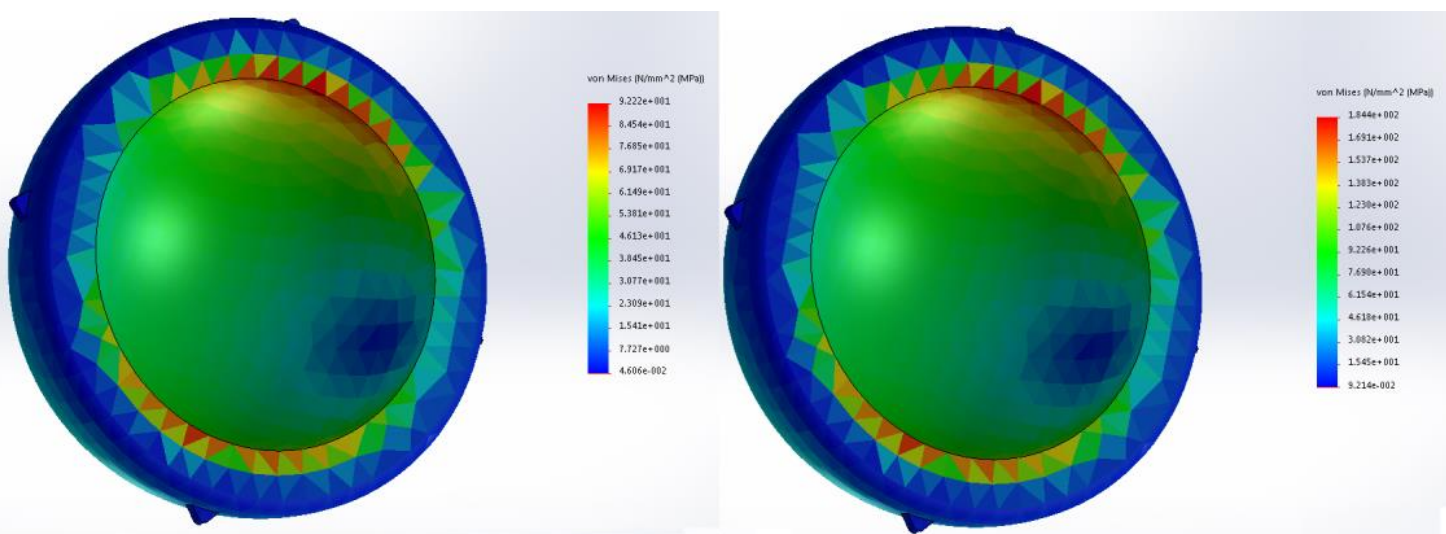

Fig. 2. Stress distribution in polyethylene socket inlays for 100 (left) and 200\%BW (right)
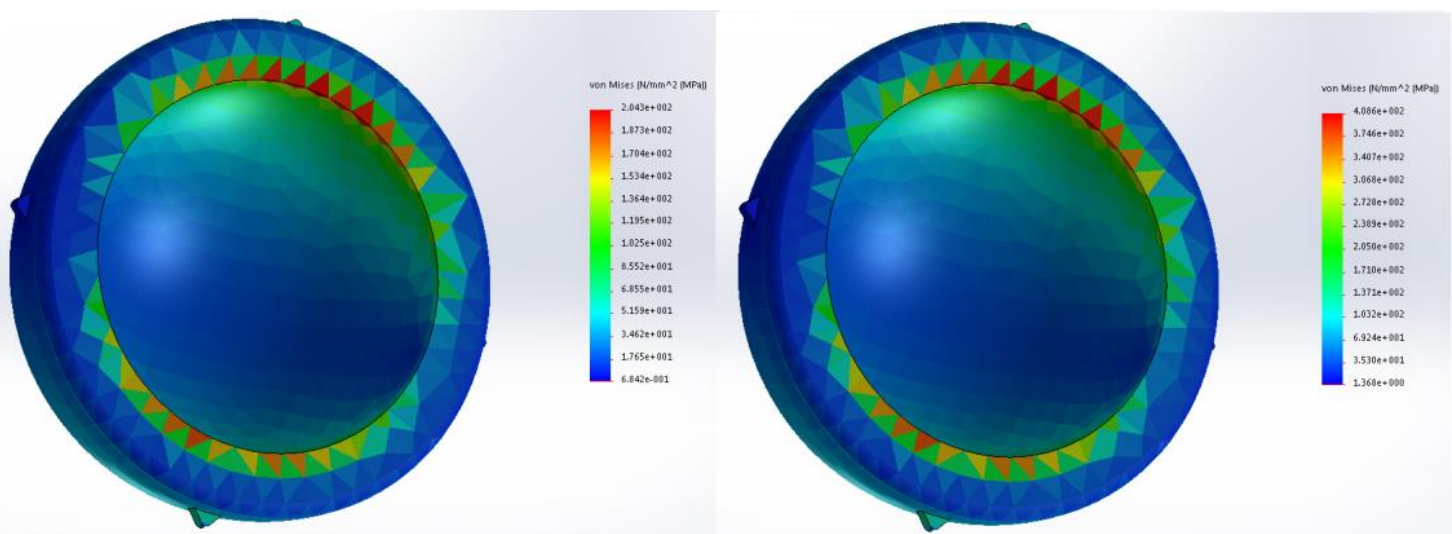

Fig. 3. Stress distribution in ceramic socket inlays for 100 (left) and 200\%BW (right)
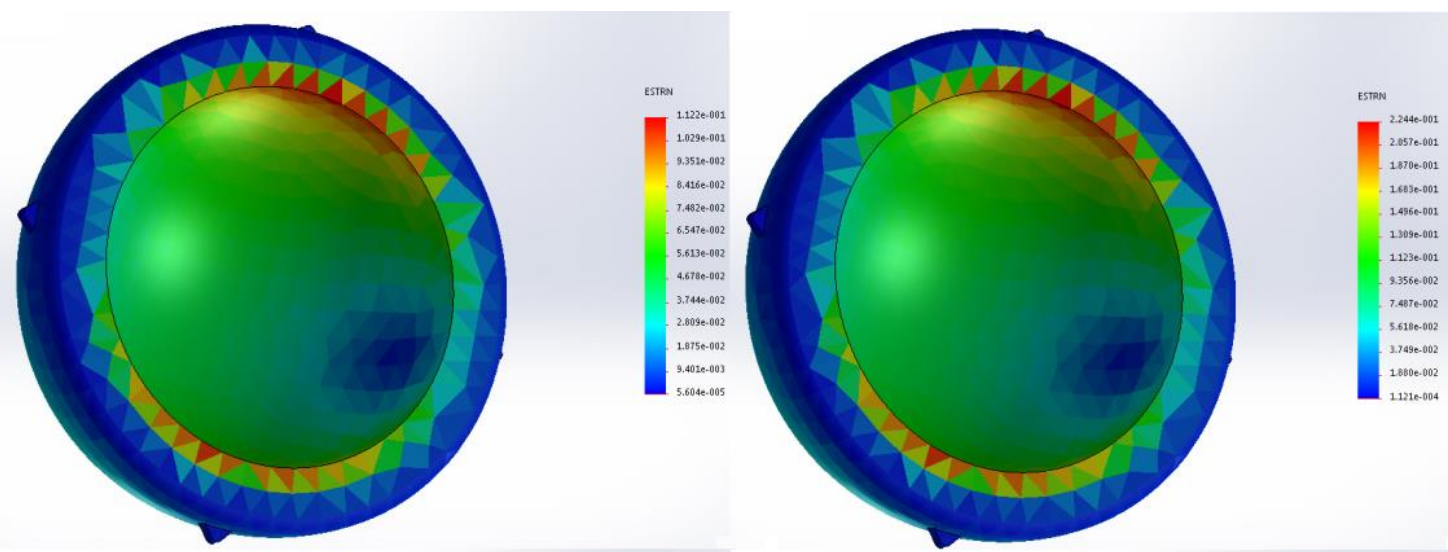

Fig. 4. Deformations in polyethylene socket inlay for 100 (left) and 200\%BW (right) 

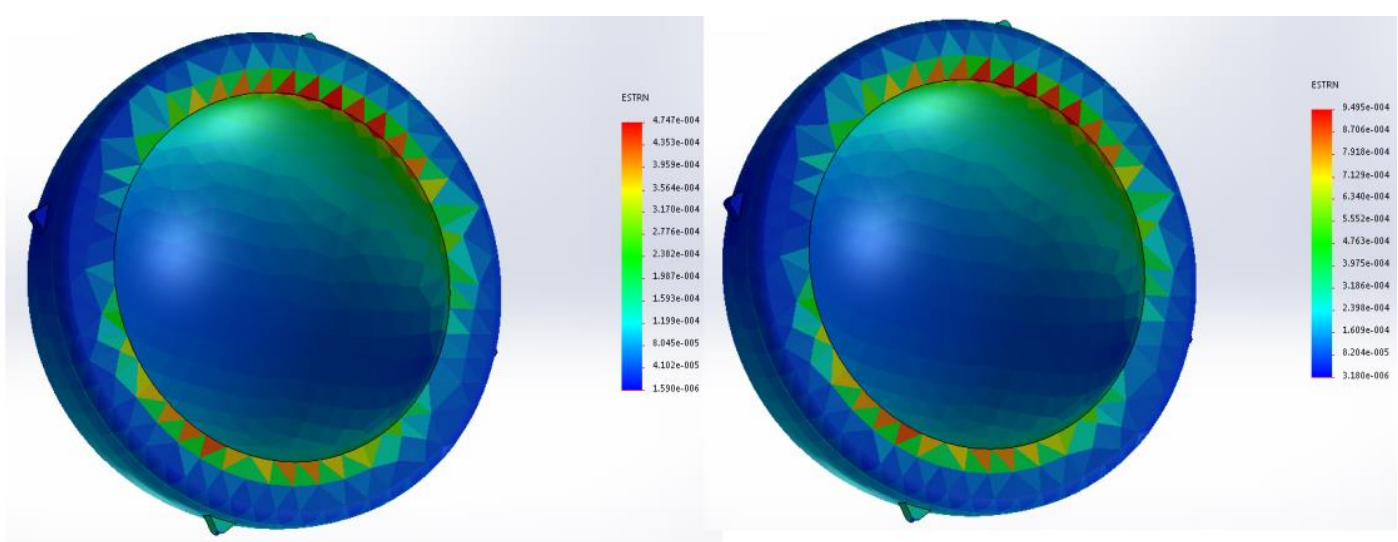

Fig. 5. Deformations in ceramic socket inlay for 100 (left) and 200\%BW (right)

Table 2. Maximum stress [MPa] in the model

\begin{tabular}{|c|r|r|}
\hline Material & 100\%BW & \multicolumn{1}{|c|}{ 200\%BW } \\
\hline Polyethylene & $9.222^{*} 10^{1}$ & $1.844 * 10^{2}$ \\
\hline Ceramic & $2.043^{*} 10^{2}$ & $4.086 * 10^{2}$ \\
\hline
\end{tabular}

Table 3. Maximum equivalent strain [-] in the model

\begin{tabular}{|c|r|r|}
\hline Material & 100\%BW & \multicolumn{1}{|c|}{ 200\%BW } \\
\hline Polyethylene & $1.122^{*} 10^{-1}$ & $2.244^{*} 10^{-2}$ \\
\hline Ceramic & $4.747 * 10^{-4}$ & $9.495^{*} 10^{-4}$ \\
\hline
\end{tabular}

The analysis shows, that the stress in the polyethylene inlay is being distributed on almost entire internal surface of the inlay with accumulation on the surface's edge and its surroundings. Maximum stress in the ceramic socket inlay is more focused around the surface of the connection with the head of the shaft and reaches maximum value twice as high as in the polyethylene inlay. Maximum deformation (as the equivalent strain) in the ceramic inlay is meanwhile twice as low as in the polyethylene socket inlay.

\section{Conclusions}

Performed study indicates the correlation between the stress distribution in the socket inlay under the influence of force and the mechanical properties of the material, of which the element has been built. Based on the results, it can be assumed that the ceramic such as a building material is superior to the polyethylene due to smaller deformations, which can lead to damages of the socket inlay and reducing the lifetime of the element. Further studies should be conducted, possibly considering other mechanical properties and their influence on changes in the socket inlay during dynamic simulation.

\section{References}

[1] R. Karpiński, Ł. Jaworski, J. Szabelski,"The design and structural analysis of the endoprosthesis of the hip joint," Applied Computer Science, vol. 12, no. 1, pp. 87-95, 2016.

[2] R. Karpiński, Ł. Jaworski, J. Zubrzycki, "Structural analysis of articular cartilage of the hip joint using finite element method," Adv. Sci. Technol. Res. J., vol. 10, no. 31, pp. 240-246, 2016.

[3] A. S. Dickinson, M. Browne, K. C. Wilson, J. R. T. Jeffers, A. C. Taylor, "Pre-clinical evaluation of ceramic femoral head resurfacing prostheses using computational models and mechanical testing," Proc. IMechE Part H: J. Engineering in Medicine, vol. 225, no. 9, pp. 866-876, 2011.

[4] H. Fang, S. M. Hsu, J. V. Sengers, Ultra-High Molecular Weight Polyethylene Wear Particle Effects on Bioactivity.Washington DC: U.S. Government Printing Office, 2003.

[5] M.Braniewska, J.Zubrzycki, R.Karpiński: Komputerowo wspomagane projektowanie i wytwarzanie implantu stawu biodrowego. Innowacje w fizjoterapii, 2, 2015, 147-170. 